\title{
Perceived Greenwashing: The Interactive Effects of Green Advertising and Corporate Environmental Performance on Consumer Reactions
}

\author{
Gergely Nyilasy \\ Lecturer in Marketing \\ Department of Management \& Marketing \\ Level 10, 198 Berkeley Street \\ The University of Melbourne VIC 3010 Australia \\ P: +61390354016 \\ gnyilasy@unimelb.edu.au
}

Harsha Gangadharbatla, Ph.D.

Assistant Professor

Associate Editor, Journal of Interactive Advertising

School of Journalism and Communication

University of Oregon | Eugene, OR 97403

Phone: 541.346.1327 | Fax: 541.346.0682

E: harsha@uoregon.edu

\author{
Angela Paladino \\ Associate Professor in Marketing \\ MSSI Theme Leader: People and Values \\ Melbourne Sustainable Society Institute, Executive \\ Department of Management \& Marketing \\ Level 10, 198 Berkeley Street \\ The University of Melbourne VIC 3010 Australia \\ P: +61 383441916 |E: a.paladino@unimelb.edu.au
}

RUNNING HEAD: Perceived Greenwashing 
Perceived Greenwashing: The Interactive Effects of Green Advertising and Corporate Environmental Performance on Consumer Reactions

Keywords: greenwashing, environmental messages, green messages, attribution theory, corporate advertising, green advertising. 


\title{
Perceived Greenwashing: The Interactive Effects of Green Advertising and Corporate Environmental Performance on Consumer Reactions
}

\begin{abstract}
The current study investigates the effects of green advertising and a corporation's environmental performance on brand attitudes and purchase intentions. A 3 X3 (firm's environmental performance and its advertising efforts as independent variables) experiment using $n=302$ subjects was conducted. Results indicate that the negative effect of a firm's low performance on brand attitudes becomes stronger in the presence of green advertising compared to general corporate advertising and no advertising. Further, when the firm's environmental performance is high, both green and general corporate advertising result in more unfavorable brand attitudes than no advertising. The study's counter-intuitive findings are explained by attribution theory.
\end{abstract}

Word Count: 100 


\section{Introduction}

A rise of green consumers had a significant impact on CSR initiatives and corporate environmental performance (Porter and Kramer 2006). Within the general CSR movement, green marketing and the need for ethical ecological conduct of companies are now firmly established (Dahlstrom 2010; Kotler 2011; Martin and Schouten 2012).

Unfortunately, along with the resurgence of green marketing, the phenomenon of greenwashing is also becoming increasingly prevalent. Greenwashing is defined as intentionally misleading or deceiving consumers with false claims about a firm's environmental practices and impact (TerraChoice 2010). Consumers are becoming very discerning and skeptical of corporations in general as many firms profess to protect the environment but fail to demonstrate that in their actions and performance. Nowhere is this more poignant than as demonstrated in the recent BP U.S. Gulf Spill crisis. As a company, Beyond Petroleum has touted its environmental credentials for a number of years with its advertising and marketing efforts and yet has contributed to one of the worst oil spills in recent history. BP's response to the spill was to employ 'Voices of BP campaign' and 'Progress Report' ads as a means to curtail the damage to its reputation and appear transparent in its actions. Since the clean-up, however, there has been a dramatic shift in the advertising tactics employed by the company. It has moved away from a proud emphasis on its green strategies to more corporate-focused ads that emphasize its efficiency as a player in the oil and gas space (Forbes 2012).

The emphasis on sustainability has been a mainstream issue for consumers for a while now (Davis 1993). Sustainable production and consumption have become organizational imperatives in today's world (e.g., Kotler 2011). However, not all companies are rewarded for being 'green' or environmentally conscious. As recognized by Easterling et al. (1996), organizations that claim 
to be sustainable are often subject to closer scrutiny from government, competitors, and consumers. This scrutiny might deter companies from advertising their sustainable goals and practices but many others continue to compete on the basis of sustainability. As espoused by Kotler (2011), we need research that helps us better understand the factors that encourage and/or hinder companies from focusing on environment and sustainability in their marketing and advertising campaigns.

Advertising is one of the most commonly employed mechanisms to communicate a green message to consumers. In fact, there has been a pronounced increase in green messages in advertising since the 1960s (Easterling et al. 1996). This increase in green messages has not always translated to favorable consumer brand attitude formation. Instead, consumers have become increasingly skeptical of the environmental claims made by some of these organizations (GfK 2010). The existence of consumer skepticism, together with perceived deception, has had a negative impact on organizational credibility, as well as perceived company performance (e.g., Webb and Mohr 1998; Newell et al. 1998; Vanhamme and Grobben 2009). These challenges are even more pronounced when reviewed in the context of a large-scale environmental catastrophes attributed to an organization.

As we will demonstrate, when green advertising (talk) and actual corporate environmental performance (deeds) interact a "perceived greenwashing effect" results. We define perceived greenwashing as consumer reactions to situations where green advertising messaging and actual corporate social responsibility interact.

The perceived greenwashing effect has great significance for green marketing research. It is important to research perceived greenwashing not just because it impacts a company's bottom 
line but also because disingenuous green communication constitutes severe ethical harms (Davis 1992) and hurt all corporations (even the ethical ones!) in the long run.

Accordingly, the purpose of this research is to investigate the interactive consumer effects of green advertising and corporate environmental performance on brand attitudes and purchase intention. The study uses attribution theory borrowed from psychology as an explanatory framework to understand consumer processing of green advertising and its impact on effectiveness of such messages. The contribution of this research is therefore twofold: (1) to provide a deeper theoretical explanation (attributions) for consumer reactions to green advertising efforts and (2) to bridge the two so far disconnected research areas: "greenwashing" as an ethical/societal/macro body of literature and consumer responses to advertising as consumer behavior/communication effects research field.

This paper is organized as follows. First, we present the theoretical background on green advertising within the context of the broader area of corporate social responsibility (CSR) and stakeholder theory. We also consider consumer psychological responses to green advertising in this section. Second, we review the literature on actual corporate environmental performance and its consumer effects. Third, we consider the interactive effects of these two independent variables on consumer outcome variables. Finally, we review the available psychology literature related to attribution theory, which serves as an explanatory theoretical framework for the interactive effects of corporate environmental performance and a firm's green advertising on consumer attitudes and purchase intentions. We then lay out our method, data collection and analysis, followed by a presentation of results and a discussion of both theoretical and practical implications. 


\section{Conceptual Development and Hypotheses}

The literature on green marketing and advertising has grown significantly in the past few decades. An array of thematic areas has been considered, including: marketing management aspects, environmental management, environmental corporate policy, external regulatory environment, environmental strategy implications, corporate environmental response, green advertising and greenwashing (Leonidou and Leonidou 2011). One of the areas that has received less attention and has been identified as a research priority is "investigating the effects of consumer perceptions of green marketing strategies toward green behaviors" (Cronin et al. 2011, p. 170). When companies engage in green advertising, how do consumers perceive these messages in light of the firm's environmental performance and other corporate social responsibility (CSR) initiatives?

\section{Green Advertising, Corporate Social Responsibility (CSR) and Consumer Responses}

Green advertising is defined as "any ad that meets one or more of the following criteria: (1) explicitly or implicitly addresses the relationship between a product/service and the bio-physical environment, (2) promotes a green lifestyle with or without highlighting a product/service, and (3) presents a corporate image of environmental responsibility" (Banerjee, Gulas, and Iyer 1995, p. 22). Corporations engage in green advertising for any of the following reasons: "(a) the emergence of a green consumer segment, (e.g., Porter and Kramer, 2006; Webb \& Mohr, 1998) (b) the greening of other stakeholder groups, notably owners [and/or stockholders], and (c) the increase in responsible business development” (Zinkhan and Carlson 1995, p. 1.).

Both from the definition and the reasons why corporations engage in green advertising, it is clear that such strategies can be (although not necessarily are) part of a firm's much broader CSR 
initiatives. When this green advertising becomes misleading, however, it is attributed to corporate greenwashing claims, which, as previously detailed, adversely impacts on CSR efforts and reputation. Corporate social responsibility (CSR) is defined as "a concept whereby companies integrate social and environmental concerns in their business operations and in their interaction with their stakeholders on a voluntary basis" (Öberseder et al. 2011, p. 451). With growing public concern for social and environmental issues, CSR is quickly becoming a top priority for corporations and business leaders (Porter and Kramer 2006).

Firms spend large amounts of money on green advertising and CSR initiatives because they want to be perceived as social and environment-friendly with the hopes that such perception would lead to more favorable brand attitudes and purchase intentions (Forbes 2012). Information about CSR initiatives on any of the three dimensions - commercial, social, and ethical - has shown to affect consumer perception of company image (Singh et al. 2008). Stakeholder theory applied to green marketing provides further insight. Polonsky $(1995,2011)$ argues that there are three main stakeholders - firms, consumers, and governments - involved in green marketing and it is their interactions that either aids or impedes the ultimate success of such strategies.

Of these three stakeholders, the role of consumers is undeniably important and complex. Consumer response to green advertising and CSR initiatives can be better understood through the general attitude change theories from psychology, marketing and advertising literature. Two such theories, the Hierarchy of Effects model (Colley 1961) and the Elaboration Likelihood Model (Petty and Cacioppo 1986), suggest that consumer involvement levels and other internal and external factors moderate the relationship between marketing communication/advertising and its impact on consumer attitudes and purchase intentions positively. 
The above marketing scholars have found ample evidence for the existence of attitudebehavior link for general advertising so it may not be too far-fetched to expect the same for green advertising. In fact, many researchers have found empirical evidence that green advertising (if at varying degrees) works. Schuhwerk and Lefkoff-Hagius (1995), for instance, showed that, especially among less environmentally concerned individuals, green appeals had a higher positive effect on attitudes and purchase intentions than non-green appeals. Similarly, Mobley et al. (1995) found that ads with green claims were more effective in generating favorable brand attitudes than were ads without green claims. Therefore, green ads do seem to elicit a favorable response from consumers, in terms of both attitudes and behavior (Henion 1972).

\section{Corporate Environmental Performance and Consumer Responses}

Green advertising is not the only factor that influences consumer attitudes when it comes to the environment: firm performance (or perceptions of performance) itself is reasonably expected to play at least an equal role. Corporate environmental performance has been defined in various ways in the literature (Delmas and Blass 2010; Gunningham 2009; Lee and Lounsbury 2011; Salo 2008; Xie and Hayase 2007). While operationalizations of the construct often differ, there appears to be a consensus in that corporate environmental performance is comprised of a firm's record of (1) environmental impact, (2) regulatory compliance and (3) organizational processes (Delmas and Blass 2010).

Research shows that environmental performance does indeed influence brand attitudes and purchase intentions (e.g., Montoro-Rios et al. 2008). This effect should not be surprising. The processing of information about the company's actual deeds should be similar to how any other information (including advertising discussed above) is being processed by consumers. In fact, the 
same attitude/behavioral change theories discussed above (Hierarchy of Effects, Elaboration Likelihood Model) should explain how such information is integrated in consumer consciousness/attitudes and behavior. From the perspective of such basic attitude change and behavioral processes the only difference is the source of information: while green advertising always originates from the company, objective information about corporate social performance often comes from direct experience or third parties (e.g., the news media, word of mouth). Whichever way corporate environmental performance becomes apparent to consumers it is expected to have an attitudinal or behavioral impact as predicted by the Hierarchy of Effects or Elaboration Likelihood Models.

What becomes particularly insightful is the effect of low environmental performance, often assessed through environmental failures, on brand attitude and purchase intentions. Information provision appears to be a key factor in consumer positive outcomes (Gunningham 2009). Providing information to the community and full disclosure help to buffer the negative effect that low environmental performance has on attitudes and purchase intentions (Salo 2008). It is in the best interest of an organization to minimize the adverse effects of a firm's low environmental performance on reputation and consumer behavior, including extremely negative consumer actions such as boycotting product purchase (Lee and Lounsbury 2011; Raju and Rajagopal 2008).

Further, Cho et al. (2012) recently investigated the extent to which a firm's environmental performance is reflected in the perceptions of its environmental reputation. While not using direct measures of brand attitudes and purchase intentions, the study does present some interesting findings in terms of consumer responses to information on a firm's environmental performance. Based on a sample of 92 firms, the authors find that environmental performance 
scores were significantly related to reputation scores. Along the same lines, Brammer and Pavelin (2006) examine a sample of large firms and find that corporate reputation is determined largely by a firm's social performance and nature of its business activities among other things. A firm's record of environmental performance can either enhance or damage its reputation depending on whether the firm's activities align with the environmental concerns of its stakeholders (Brammer and Pavelin 2006). While these two studies deal with the more general concept of corporate reputation, they present direct implications for our study as corporate reputations is often associated with attitude toward the company, brand and purchase intentions.

\section{Interaction Between Green Advertising and Corporate Environmental Performance}

Green advertising and corporate environmental performance both independently have an impact on consumer brand attitudes and purchase intentions. But what happens when both factors are presented simultaneously to consumers (as is often the case in real life settings)? As Easterling et al. (1996) suggest when firms underperform environmentally, green advertising may become "more of a liability than a benefit" (p. 20). The greenwashing literature also suggests the possibility of an interaction between advertising and environmental performance (Alves 2009; Delmas and Burbano 2011; Furlow 2010; Gillespie 2008; Greer and Bruno 1996; Paladino and Pandit 2012; Ramus and Montiel 2005; TerraChoice 2010). While this literature is largely ethical, legal or macro-societal and not consumer behavioral/psychological in its focus, it has implications for experimental research.

The greenwashing literature offers much qualitative and anecdotal evidence that firms often do not do what they say (e.g., Alves 2009; Furlow 2010; Gillespie 2008). Therefore, consumers often face contradicting stimuli about a firm's performance and its advertising. It is 
reasonable to hypothesize that consumers react to such contradiction in ways that are often described as interactive effects in experimental research - indeed the greenwashing literature (1) demonstrates that such skepticism exists and (2) attempts to increase this level of skepticism through exposing corporate misconduct.

Translating this perceived greenwashing effect to the language of psychology, consumers may react in a skeptical way to such contradictions between talk and action. For instance, encountering green advertising messaging may have a more positive attitudinal/behavioral effect when consumers also learn about high corporate performance than when they learn about negative performance. In other words, the impact of green advertising depends on the level of a different independent variable, corporate environmental performance - the two interact in terms of its impact on consumer outcome variables.

\section{Attribution Theory}

In order to better understand the consumer-perceived greenwashing effect presented above we need to examine the psychological mechanisms that underlie the processing of simultaneous green advertising and corporate environmental performance stimuli. Attribution theory provides the most salient explanatory theoretical framework because it has been successfully used in the past in marketing/advertising for situations which involve consumer skepticism and its ultimate effects.

Developed in the general psychology literature (Harvey and Weary 1984; Heider 1944; Kelley 1971; Kelley and Michela 1980), attribution theory investigates the lay causal explanations people give when being confronted with others' behavior in social environments. By way of analogy, attribution theory has been successfully employed in many areas of 
consumer behavior (such as sales, advertising, and customer relationship management), stating that consumers demonstrate similar attributional processes when encountering the "behavior" of corporations (in the form of talks or acts) to what they do with observed human behavior (Folkes 1988; Mizerski et al. 1979; Oliver 1993; Weiner 1986, 2000). It is significant that the simple attitude change theories we referenced above (Colley 1961; Petty and Cacioppo 1986), explaining how consumers process information, let it be advertising or information on corporate performance, may not be entirely correct when attributional processes quick in. Attributional processes complicate attitude change and if skeptical attributions appear, such attributions may hinder positive attitude/behavior change (Friestad and Wright 1994).

Similarly, research on Corporate Social Responsibility (CSR) suggests that attributional processes are present in consumers' evaluations of a firm's CSR messages and actions (Ellen et al. 2006; Forehand and Grier 2003; Geue and Plewa 2010; Klein and Dawar 2004; Swaen and Vanhamme 2004; Vlachos et al. 2009; Webb and Mohr 1998; Yoon et al. 2006).

Because green marketing is a subset of CSR, it is plausible to apply these same theoretical explanatory tools when analyzing the consumer effects of green advertising and corporate environmental performance and their interaction.

As discussed earlier, firms often employ CSR initiatives to communicate corporate character and to develop the support of consumers towards the organization and its products. Despite this, consumers respond negatively to CSR initiatives that they perceive as exclusively stakeholder-driven or egoistic. The attributions that they form, in turn, affect brand attitudes and purchase intent negatively (Walker et al. 2010). The fit between the company's core business and their selected cause and length of commitment also affects consumer attributions. The lower the perceived fit by consumers, the higher would be the egoistic attributions applied (Ellen et al. 
2006; Forehand and Grier 2003). Further, higher levels of perceived deception by consumers were associated with lower organizational credibility, lower favorable attitudes towards the ad and brand and decreased intentions to the product being advertised (Newell et al. 1998).

If a firm adheres to moral standards, a quality reputation would enhance consumer attitudes towards the firm and its products. In fact, organizations are held accountable for action rather than inaction. Thus, if a firm that espouses ethical standards engages in an ethical breach, consumer attitudes will decrease more so than if an alternate firm who did not espouse ethical standards was engaged in the same behavior (Folkes and Kamins 1999). This is supported by Vanhamme and Grobben (2009) who showed that companies facing a crisis should be wary of using CSR as a defense tool; company image is fragile when disaster hits. Firms employing CSR for a longer period of time may earn the right to do so, but for those employing CSR only recently, this action triggers consumer skepticism regarding the firm motivations (Vanhamme and Grobben 2009). These perceived ethical violations result in attributions of deception, which have consequences for attitudes and purchase intent (Webb and Mohr 1998; Groza et al. 2011). In conclusion, there is strong evidence that attributional processes mediate the impact of CSR on the subsequent consumer attitudes and intentions (Forehand and Grier 2003; Yoon et al. 2006).

\section{Hypotheses}

Given the relationship between CSR and consumer response and the mediating role of attributional processes, it is a natural extension to expect similar relationships for environmental messages. To our knowledge, there are no studies that directly link and apply attribution theory to green advertising. The scarce literature on environmental attributions in green advertising

(Davis 1994; Newell et al. 1998) does show that attributional consumer processes exist; 
however, it does not specify how such consumer reactions vary based on green advertising contrasted with actual corporate environmental performance observed. Thus, in our research, we will test the hypotheses that green ad messages and a firm's environmental performance interact in their effects on attitudes towards the firm as well as purchase intentions. Accordingly, and in line with the argument of the previous pages, we state the following two hypotheses (one for consumer attitudes, one for purchase intentions):

H1: There is an interaction effect between green advertising messaging and firms' environmental performance such that the negative impact of low performance on brand attitude is strengthened by the presence of green advertising messaging (vs. general corporate advertising and no advertising).

H2: There is an interaction effect between green advertising messaging and firms' environmental performance such that the negative impact of low performance on purchase intent is strengthened by the presence of green advertising messaging (vs. general corporate advertising and no advertising).

\section{Method}

\section{Research Design}

In order to test the hypotheses, a between-subjects experiment was designed with two independent variables of three levels each (3X3). The manipulated factors were firm environmental performance (three-levels: high performance vs. low performance vs. no performance information given) and green advertising messaging (three-levels: advertising with green message vs. general corporate advertising message vs. no advertising stimulus). General corporate advertising was used as a third level to control for the potential general effects of advertising (irrespective of its content) - a similar design was used by Parguel et al. (2011). The basic design of our study is illustrated in Table 1.

\section{[PLACE TABLE 1 ABOUT HERE]}


The dependent variables were attitude toward the brand and purchase intentions. For these, validated scales from the advertising literature were used. Attitude scales for brand, company, and chemical industry were measured using multiple-item, 7-point semantic differential scale adapted from Muehling and Laczniak (1988). These items included measures such as good/bad, favorable/unfavorable, positive/negative, etc. The purchase intention scale was a single-item, 7point version adapted from Mitchell and Olson (1981) asking respondents how likely they were to purchase the product advertised.

\section{Participants}

An email invitation to participate in our study was sent to a total of 4000 randomly selected students in a large university in the U.S. in 2012. Of these respondents, 496 initiated the experiment and ultimately 302 of them completed it fully. Subjects were informed that the purpose of the study was to understand their attitudes and beliefs toward corporate advertising; there was no mention of "green" or "green advertising" to avoid response bias. The experiment took 20 minutes to complete. Subjects were informed that participation is purely voluntary and that they could stop at any point during the survey. They were also promised that all information collected would be kept strictly anonymous and analyses would only be on aggregate level. The study was approved by the university's Institutional Review Board (IRB) for compliance with Human Subjects research. As an incentive, ten randomly drawn participants were offered a $\$ 20$ gift card from a local bookstore. 


\section{Stimulus Development}

To manipulate the first independent variable (green messaging), print ads (one green ad and one general corporate ad control) were developed for a fictitious company (PWXL Chemical Co.). The experimental ad stimulus contained a green message detailing the fictitious company's green efforts, the control ad stimulus carried a positive but bland corporate message (describing the company's innovative and positive corporate image, but avoiding any specifics). To manipulate the second independent variable, corporate environmental performance, written scenarios describing high and low performance events were constructed.

The stimulus development process contained the following steps.

First, after a review of corporate ads in business publications (such as Fortune, The Economist, Harvard Business Review, etc.) and stimulus used in similar studies in the literature (e.g., Schuhwerk and Lefkoff-Hagius 1995), an initial draft version of advertising and environmental performance scenario items were developed. Corporate environmental scenarios were written after consulting the literature on the concept (Delmas and Blass 2010; Gunningham 2009).

Second, five faculty members in advertising and marketing provided qualitative feedback. As a result, the text of the ads and scenarios were slightly modified. In particular, wording was adjusted to better match everyday language.

Third, the ads were crafted by design professionals. In consultation with the designers, various designs were vetted by the authors and emphasis was placed on clear communication and professional production values. The final ads were laid out in InDesign.

Fourth, the professionally produced stimulus ads and scenarios were qualitatively pretested by undergraduate students, separate from the main sample. The qualitative feedback suggested 
that the ads and scenarios clearly communicated the message intended and were perceived as realistic.

Finally, a quantitative pretest/manipulation check was conducted. An independent sample of $69(n=69)$ students were shown the two ads on a large screen in a classroom and asked to rate their agreement or disagreement with two statements after exposure to each ad. Likert-type scales (1-5) were employed to measure how strongly the subjects agreed or disagreed with the statements. The statements were (a) "The ad suggests that PWXL is an innovative company" and (b) "The ad suggests that PWXL is an environmentally friendly company." In order to test how subjects perceived both the ads, we ran a paired-samples t-test to compare means. For the test ad (with the environmental message), as expected, subjects rated the company environmentally friendly $(M=4.19)$ more so than innovative (message of the general corporate control ad) $(\mathrm{M}=3.25)$. The control ad resulted in subjects rating the fictitious company innovative $(\mathrm{M}=3.14)$ more so than environmentally friendly $(\mathrm{M}=2.32)$. All differences were significant at $p<0.001$. These results suggest that the experimental manipulation significantly differed from the control ad and the intended message (environmental focus) was taken away.

Please see Appendix 1 for the final versions of the ads and firm performance scenarios used in our study.

\section{Main Experiment Procedures}

Upon receiving an email invitation with a link to the web-hosted stimuli and questionnaire, subjects could either participate in our study by clicking that link or be asked to be removed from our panel by clicking a separate link. As noted earlier, a total of 496 individuals clicked on our survey link of which 302 fully completed the post-exposure questionnaire. Subjects were 
assigned randomly to the eight possible cells (see below). Data was collected over a period of two weeks in 2012 and was hosted on a local web server.

The stimuli and post-exposure questionnaire were both designed using survey design software Qualtrics in English language. The landing page of our study included contact information, IRB number, and some basic statements about the purpose of our study. Once subjects clicked OK and agreed to participate, they were treated to one of the eight scenarios as detailed in the research design. Although our design (3X3) called for a total of nine cells, collecting attitudinal data about a fictitious company under the condition where there was no ad and no performance message would have been unintelligible for respondents. Therefore, data was collected for only eight of the nine cells. Subjects were exposed to only one condition where they either saw an ad or an ad followed by performance information or just the performance information with no ad. After the exposure to one of the stimulus-combinations, the dependent variables (attitude toward the brand, purchase intent) were measured. At the end of the survey a covariate used in the analysis (industry attitude) was measured on a 5-point Likert-type scale as well as two demographic questions: age and gender. No further demographic information was collected to maintain anonymity. After completing the study, respondents were directed to an acknowledgement page that thanked them for their participation.

\section{Results}

As reported earlier, the study resulted in a total of $\mathrm{N}=302$ participants of which 104 (35\%) were male, $188(62 \%)$ were female and 10 choosing not to respond. Participants ranged from ages 18 to 48 with majority of them (90\%) falling under the age of 25 . The distribution of subjects in each cell is as shown in Table 2. 


\section{[PLACE TABLE 2 ABOUT HERE]}

Reliability assessment was conducted for all scales using Cronbach's $\alpha$ with all exceeding the generally accepted guideline of 0.70 (Hair et al. 2010, p.118). The mean scores, variances and reliability indices were the following: attitude toward the chemical industry (6 items, $M=2.3$, Variance $=0.19, \alpha=0.90$ ); attitude toward brand ( 3 items, $M=3.6$, Variance $=2.6, \alpha$ ranged from 0.92 to 0.96$)$. Purchase intention was a one-item scale.

\section{Testing Hypothesis 1}

Our first hypothesis predicted an interaction effect between a firm's environmental performance and its green advertising messaging efforts. More precisely, we expected that the negative impact of low performance on brand attitude was strengthened by the presence of a green advertising message. In order to test this hypothesis, an analysis of variance (two-way ANOVA) with firm's performance and advertising efforts as independent variables and attitude toward the company as a dependent variable was conducted. The results are summarized in Tables 3 and 4 below.

\section{[PLACE TABLES 3 AND 4 ABOUT HERE]}

As seen in the tables above, the interaction of IV1 (advertising message types) and IV2 (corporate environmental performance) is significant at $p<0.01$, which suggests that attitude toward the brand (the dependent variable) depends on the interaction between the independent variables. In order to further investigate this, a post-hoc Tukey analysis was conducted. The results of the mean differences and their significance levels and a means plot are depicted below in Table 5 and Figure 1.

\section{[PLACE TABLE 5 AND FIGURE 1 ABOUT HERE]}


When advertising is followed by a high performance message, attitude toward the brand is most favorable for no advertising ( $M=5.1)$, followed by environmental ad $(M=4.2)$, followed by general corporate ad $(\mathrm{M}=4.1)$. The order is reversed when the ad is followed by a negative performance message with attitude toward brand being the most favorable for corporate ad $(\mathrm{M}=2.8)$, followed by environmental ad $(\mathrm{M}=2.5)$ and no ad $(\mathrm{M}=2.1)$. Under the no message or

performance information condition, the corporate ad $(\mathrm{M}=4.1)$ outperforms the environmental ad $(\mathrm{M}=3.7)$.

In order to better understand the interaction between the firm's advertising strategies and its environmental performance, our two independent variables, we introduced a covariate into our design. This was done to control for the effects of using a brand from a particular industry (the chemical industry) in our study. As we assigned subjects randomly to each cell, we wanted to see if the interaction holds after controlling for individuals' pre-existing attitudes towards the chemical industry as a whole. Randomly assigning subjects to each cell means the expected mean value of the covariate will be the same for each cell and any or all differences can be attributed to chance alone. Table 6 below summarizes the results of ANCOVA.

\section{[PLACE TABLE 6 ABOUT HERE]}

\section{Testing Hypothesis 2}

Our second hypothesis predicted another interaction effect between the two independent variables (green advertising messaging and environmental performance) for the dependent variable (purchase intention). Another two-way ANOVA with dependent variable purchase intention was conducted and Tables 7, 8, 9 and Figure 2 below summarize our findings. 
The interaction effect was not significant at $p<0.05$ level, which led us to interpret the significant main effect, the corporate environmental performance effect. Our results suggest that unlike attitudes, purchase intentions are only influenced by the type of performance information (high performance vs. low performance vs. no performance information) but not by the interaction of this information with the type of advertising communicated.

In order to further explore this issue, we included "attitude toward chemical industry" as a covariate in our analysis and conducted an ANCOVA. The addition of a covariate resulted in a significant interaction effect. Table 10 summarizes the result of the ANCOVA.

\section{[PLACE TABLE 10 ABOUT HERE]}

Given this significant interaction effect upon adding a covariate, we found support for a modified version of Hypothesis 2. Controlling for attitudes toward chemical industry, there is a significant interaction effect between green advertising and a firm's environmental performance such that the negative impact of low performance on purchase intention is strengthened by the presence of a green ad (as opposed to a corporate ad or no ad).

\section{Discussion}

Controlling for pre-existing industry attitudes, we found initial evidence for an interaction between the effects of green advertising and corporate environmental performance in their impact on consumer brand attitudes and purchase intentions. Contrary to what basic attitude change expectations would suggest (that green advertising would additively move consumer attitudes in a positive direction, irrespective of the level of corporate environmental performance), green advertising can in fact harm companies - it may be that some firms would be better off staying silent. 
One important qualification in interpreting these results is that while this overall interaction effect is significant, its magnitude is relatively small - indeed, our Tukey post hoc tests did not show significant differences in brand attitudes/purchase intentions under the negative performance scenario as a function of green vs. general CSR vs. no advertising message strategies. While, these differences are not significant, they are in the direction of our theoretical hypotheses. Further, under positive environmental performance scenarios, green advertising (or even general CSR advertising) can interfere with consumers" "organic" evaluations of companies: the no-advertising strategy resulted in the highest scores on brand attitudes and purchase intentions even when the company "did well" environmentally speaking.

The explanation we have offered for these somewhat counterintuitive findings lies in attribution theory. Our results suggest that consumers may become skeptical when they see discrepant green advertising and corporate performance. Consumers may start to form negative attributions about the motives of the company, attributing them ulterior motives. In other words, they observe companies engaging in "greenwashing": firms not doing what they preach. Such internal processes in turn "upset" the normal additive process of attitude formation - the process by which positive stimuli such as green advertising progressively builds green credentials and shifts attitudes and purchase intentions in a positive direction. Attributional processes may "stand in the way" - they may mediate the combined effects of performance and communication (Friestad and Wright 1994).

These findings are in line with articles in the CSR literature utilizing attribution theory. Forehand and Grier (2003) find that skeptical consumer attributions lower corporate brand evaluations when there is an inconsistency between the stated goals of the firm and the type of benefits the firm receives. Similarly, Folkes and Kamins (1999) find that there is an interaction 
effect between product information communicated and firm ethical behavior: "Confirming principles drawn from evaluations of individuals, results showed that a superior product attribute enhances attitudes toward ethically behaving firms more than toward unethically behaving firms" (p. 243). Finally, Ellen et al. (2006) find that discrepancies between ethical causes supported and the firm's business interests result in lower evaluations and purchase intent due to mediating attributional processes: "Consumers responded most positively to CSR efforts they judged as values driven and strategic while responding negatively to efforts perceived as stakeholder driven or egoistic. Attributions were shown to affect purchase intent as well as mediate the structure of an offer" (p. 147).

While the CSR domain is broader and more general than the more narrowly defined green advertising domain, the correspondence in findings testifies about the usefulness of attribution theory for this line of research as well.

\section{Implications}

Attribution theory appears to be a fruitful explanatory mechanism for future studies about the effectiveness of green marketing strategies. As shown in our research, green advertising efforts can easily backfire - especially, when they are discrepant with actual environmental performance. Consumer causal explanations for why companies engage in green advertising activities may contain negative attributions, those of insincerity, opportunism and egotism.

Managers handling green advertising initiatives should be aware of the importance of consumer attributions. We have three recommendations for managers.

First, the naïve view that benevolent green advertising can only help brand attitudes and purchase intent should be rejected. As our results show, green advertising can easily backfire, 
especially, under negative performance scenarios. As one may wonder about certain elements of BP's corporate communications (advertising or otherwise), some efforts may very well be “oil on fire." Our study also shows that "greenwashing" is not merely an ethical issue. Consumer perceptions of greenwashing are real and their impact on brand attitudes and purchase intent is significant. Green advertising does not only have ethical consequences but also consumer perception and ultimately business/financial ones. In line with Kotler's (2011) recommendations, we suggest ethical green advertising/marketing is conducive to good business results.

The second recommendation is that green consumer attributions need to be researched and their formation and influence anticipated in strategic communication moves. In our view, the best policy is "do as you say" (as often suggested by reputation economists: Kerton and Bodell 1995; Klein and Leffler 1981). However, even then consumer skepticism may form (potentially as a result of past failures or general consumer suspicion due to industry history or indeed, the growing general concerns about the environment). Therefore accurate consumer intelligence on environmentally-related attributions is critical under all scenarios.

Finally, it is important to note that understanding what the consumer is sensitive to is only the first step. Delivering on such expectations in an ethically responsible manner is the ultimate goal. In the array of strategies available, some companies may in fact be better off not advertising "their green" at all - if research shows that the attributional risk is too high. Under such scenarios, improving corporate environmental performance instead is a better investment.

\section{Limitations and future research}

As all research, our study has some limitations. First, in order to maximize internal validity, experiments may be limited in their external validity. While we did everything in our 
power to make sure our experimental stimulus materials are as realistic as possible (see the multistep stimulus development approach above) and were keen to use validated dependent variable scales, external validity may remain an issue. Future quasi-experimental or fieldexperimental designs can complement our more conservative approach. Industry collaborations and case studies can provide further cross-validation. Second, as common practice in experimental psychology and communication research we used a student sample. While stimulus materials were introduced to subjects randomly, it is possible that younger generations are more informed about green issues and this could have potentially influenced our results. Larger scale surveys on general populations with structural equation modeling analysis techniques can again complement our work. Furthermore, future studies could compare our student sample to a sample from an environmental group to examine any significant differences that could potentially arise. Finally, our study is limited to the United States. However, cross-cultural factors may influence the nature of attributions and therefore result in different outcomes in the dependent variables of brand attitude and purchase intent. Future cross-cultural research is recommended to account for such cultural factors.

Future research should also investigate the specific content of such attributions prevalent in green advertising. As Webb and Mohr (1998) and Ellen et al. (2006) suggest consumer attributions about firms' ethical behavior are complex and have an array of forms: strategic, egoistic, values driven and stakeholder driven attributions. Future studies can specify under what conditions what types of attributions would dominate in green advertising and with what effect. Our results have shown that the industry context matters: the interaction between advertising and performance became more pronounced on purchase intent when controlling for pre-existing industry attitudes. Certain industries are inherently more or less risky in terms of environmental 
failure and as a result may be more or less prone to consumer skepticism around green communication and behavior. More research is needed to evaluate the moderating impact of industry risk/attitudes. 
Tables, figures

\section{TABLE 1}

Study Design: 3x3 Between-Subjects Experiment

\begin{tabular}{l|ccc} 
IVs & $\begin{array}{c}\text { Green } \\
\text { ad }\end{array}$ & $\begin{array}{c}\text { General corporate } \\
\text { ad }\end{array}$ & $\begin{array}{c}\text { No } \\
\text { ad }\end{array}$ \\
\hline $\begin{array}{l}\text { High corporate } \\
\text { environmental performance }\end{array}$ & All DVs measured & All DVs measured & All DVs measured \\
$\begin{array}{l}\text { Low corporate } \\
\text { environmental performance }\end{array}$ & All DVs measured & All DVs measured & All DVs measured \\
$\begin{array}{l}\text { No corporate } \\
\text { environmental performance }\end{array}$ & All DVs measured & All DVs measured & (no data collected)
\end{tabular}


TABLE 2

Distribution of Subjects in Study Cells

\begin{tabular}{l|ccc} 
IVs & $\begin{array}{c}\text { Green } \\
\text { ad }\end{array}$ & $\begin{array}{c}\text { General corporate } \\
\text { ad }\end{array}$ & $\begin{array}{c}\text { No } \\
\text { ad }\end{array}$ \\
\hline $\begin{array}{l}\text { High corporate } \\
\text { environmental performance }\end{array}$ & 33 & 30 & 48 \\
$\begin{array}{l}\text { Low corporate } \\
\text { environmental performance }\end{array}$ & 39 & 29 & 48 \\
$\begin{array}{l}\text { No corporate environmental } \\
\text { performance }\end{array}$ & 43 & 32 & (no data collected)
\end{tabular}


TABLE 3

\section{Analysis of Variance Table for Brand Attitude}

\begin{tabular}{lrrrrr}
\hline Source & \multicolumn{1}{c}{$\boldsymbol{S S}$} & $\boldsymbol{d f}$ & $\begin{array}{c}\text { Mean } \\
\text { square }\end{array}$ & $\boldsymbol{F}$ & $\boldsymbol{p}$ \\
\hline Between treatments & 304.007 & 7 & 43.430 & 26.508 & .000 \\
$\quad$ Green advertising & 5.300 & 2 & 2.650 & 1.617 & .200 \\
$\quad$ Corporate environmental performance & 225.794 & 2 & 112.897 & 68.908 & .000 \\
$\quad \begin{array}{l}\text { Green advertising x } \\
\text { Corporate environmental performance }\end{array}$ & 29.663 & 3 & 9.888 & 6.035 & .001 \\
$\quad$ & 471.854 & 288 & 1.638 & & \\
Within treatments & 4651.000 & 296 & & & \\
\hline Total & & & & & \\
\hline
\end{tabular}

Dependent variable: Brand attitude 
TABLE 4

\section{Dependent Variable Brand Attitude Means}

\begin{tabular}{llrrrr}
\hline $\begin{array}{l}\text { Green } \\
\text { advertising }\end{array}$ & $\begin{array}{l}\text { Corporate } \\
\text { environmental } \\
\text { performance }\end{array}$ & Mean & SD & & 95\% confidence interval \\
& & & & $\begin{array}{l}\text { Lower } \\
\text { bound }\end{array}$ & $\begin{array}{l}\text { Upper } \\
\text { bound }\end{array}$ \\
\hline Green ad & High & 4.229 & .226 & 3.784 & 4.675 \\
& Low & 2.518 & .208 & 2.109 & 2.926 \\
& No & 3.786 & .198 & 3.397 & \\
\hline \multirow{2}{*}{ General corporate ad } & High & 4.144 & .234 & 3.684 & 4.604 \\
& Low & 2.815 & .246 & 2.330 & 3.300 \\
& No & 4.118 & .230 & 3.666 & 4.571 \\
\hline \multirow{2}{*}{ No } & High & 5.160 & .185 & 4.796 & 5.523 \\
& Low & 2.194 & .185 & 1.831 & 2.558 \\
& No & $-{ }^{\mathrm{a}}$ & - & - & - \\
\hline
\end{tabular}

Dependent variable: Brand attitude

${ }^{a}$ This level combination of factors is not observed, thus the corresponding population marginal mean is not estimable. 
TABLE 5

\section{Tukey Post Hoc Test for Dependent Variable Brand Attitude}

\begin{tabular}{|c|c|c|c|c|c|c|c|}
\hline \multirow{2}{*}{$\begin{array}{l}\text { Corporate } \\
\text { environmental } \\
\text { performance }\end{array}$} & \multirow{2}{*}{$\begin{array}{l}\text { Green } \\
\text { advertising } \\
\text { (A) }\end{array}$} & \multirow{2}{*}{$\begin{array}{l}\text { Green } \\
\text { advertising } \\
\text { (B) }\end{array}$} & \multirow{2}{*}{$\begin{array}{c}\text { Mean } \\
\text { difference } \\
(A-B)\end{array}$} & \multirow{2}{*}{$S D$} & \multirow{2}{*}{$p$} & \multicolumn{2}{|c|}{$\begin{array}{l}95 \% \text { confidence } \\
\text { interval }\end{array}$} \\
\hline & & & & & & $\begin{array}{l}\text { Lower } \\
\text { bound }\end{array}$ & $\begin{array}{l}\text { Upper } \\
\text { bound }\end{array}$ \\
\hline \multirow[t]{3}{*}{ High } & Green ad & $\begin{array}{l}\text { General corporate ad } \\
\text { No ad }\end{array}$ & $\begin{array}{r}.085 \\
-.931\end{array}$ & $\begin{array}{l}.325 \\
.292\end{array}$ & $\begin{array}{l}.795 \\
.002\end{array}$ & $\begin{array}{r}-.556 \\
-1.506\end{array}$ & $\begin{array}{r}.725 \\
-.356\end{array}$ \\
\hline & General corporate ad & $\begin{array}{l}\text { Green ad } \\
\text { No ad }\end{array}$ & $\begin{array}{r}-.085 \\
-1.015\end{array}$ & $\begin{array}{l}.325 \\
.298\end{array}$ & $\begin{array}{l}.795 \\
.001\end{array}$ & $\begin{array}{r}-.725 \\
-1.602\end{array}$ & $\begin{array}{r}.556 \\
-.429\end{array}$ \\
\hline & No ad & $\begin{array}{l}\text { Green ad } \\
\text { General corporate ad }\end{array}$ & $\begin{array}{r}.931 \\
1.015\end{array}$ & $\begin{array}{l}.292 \\
.298\end{array}$ & $\begin{array}{l}.002 \\
.001\end{array}$ & $\begin{array}{l}.356 \\
.429\end{array}$ & $\begin{array}{l}1.506 \\
1.602\end{array}$ \\
\hline \multirow[t]{3}{*}{ Low } & Green ad & $\begin{array}{l}\text { General corporate ad } \\
\text { No ad }\end{array}$ & $\begin{array}{r}-.297 \\
.323\end{array}$ & $\begin{array}{l}.322 \\
.278\end{array}$ & $\begin{array}{l}.357 \\
.246\end{array}$ & $\begin{array}{l}-.931 \\
-.224\end{array}$ & $\begin{array}{l}.337 \\
.870\end{array}$ \\
\hline & General corporate ad & $\begin{array}{l}\text { Green ad } \\
\text { No ad }\end{array}$ & $\begin{array}{l}.297 \\
.620\end{array}$ & $\begin{array}{l}.322 \\
.308\end{array}$ & $\begin{array}{l}.357 \\
.045\end{array}$ & $\begin{array}{r}-.337 \\
.014\end{array}$ & $\begin{array}{r}.931 \\
1.226\end{array}$ \\
\hline & No ad & $\begin{array}{l}\text { Green ad } \\
\text { General corporate ad }\end{array}$ & $\begin{array}{l}-.323 \\
-.620\end{array}$ & $\begin{array}{l}.278 \\
.308\end{array}$ & $\begin{array}{l}.246 \\
.045\end{array}$ & $\begin{array}{r}-.870 \\
-1.226\end{array}$ & $\begin{array}{r}.224 \\
-.014\end{array}$ \\
\hline \multirow[t]{3}{*}{ No } & Green ad & $\begin{array}{l}\text { General corporate ad } \\
\text { No ad }\end{array}$ & $\begin{array}{r}-.333 \\
-{ }^{a}\end{array}$ & $\begin{array}{r}.303 \\
-\end{array}$ & $\begin{array}{r}.273 \\
-\end{array}$ & $\begin{array}{r}-.929 \\
-\end{array}$ & $\begin{array}{r}.264 \\
-\end{array}$ \\
\hline & General corporate ad & $\begin{array}{l}\text { Green ad } \\
\text { No ad }\end{array}$ & $\begin{array}{r}.333 \\
-\mathrm{a}\end{array}$ & $\begin{array}{r}.303 \\
-\end{array}$ & $\begin{array}{r}.273 \\
-\end{array}$ & -.264 & $\begin{array}{r}.929 \\
-\end{array}$ \\
\hline & No ad & $\begin{array}{l}\text { Green ad } \\
\text { General corporate ad }\end{array}$ & $\begin{array}{ll}{ }^{\mathrm{a}} \\
{ }^{\mathrm{a}}\end{array}$ & $\begin{array}{l}- \\
-\end{array}$ & $\begin{array}{l}- \\
-\end{array}$ & $\begin{array}{l}- \\
-\end{array}$ & $\begin{array}{l}- \\
-\end{array}$ \\
\hline
\end{tabular}

Dependent variable: Brand attitude

${ }^{a}$ This level combination of factors is not observed, thus the corresponding population marginal mean is not estimable. 


\section{FIGURE 1}

\section{Interaction Means Plot for Dependent Variable Brand Attitude}

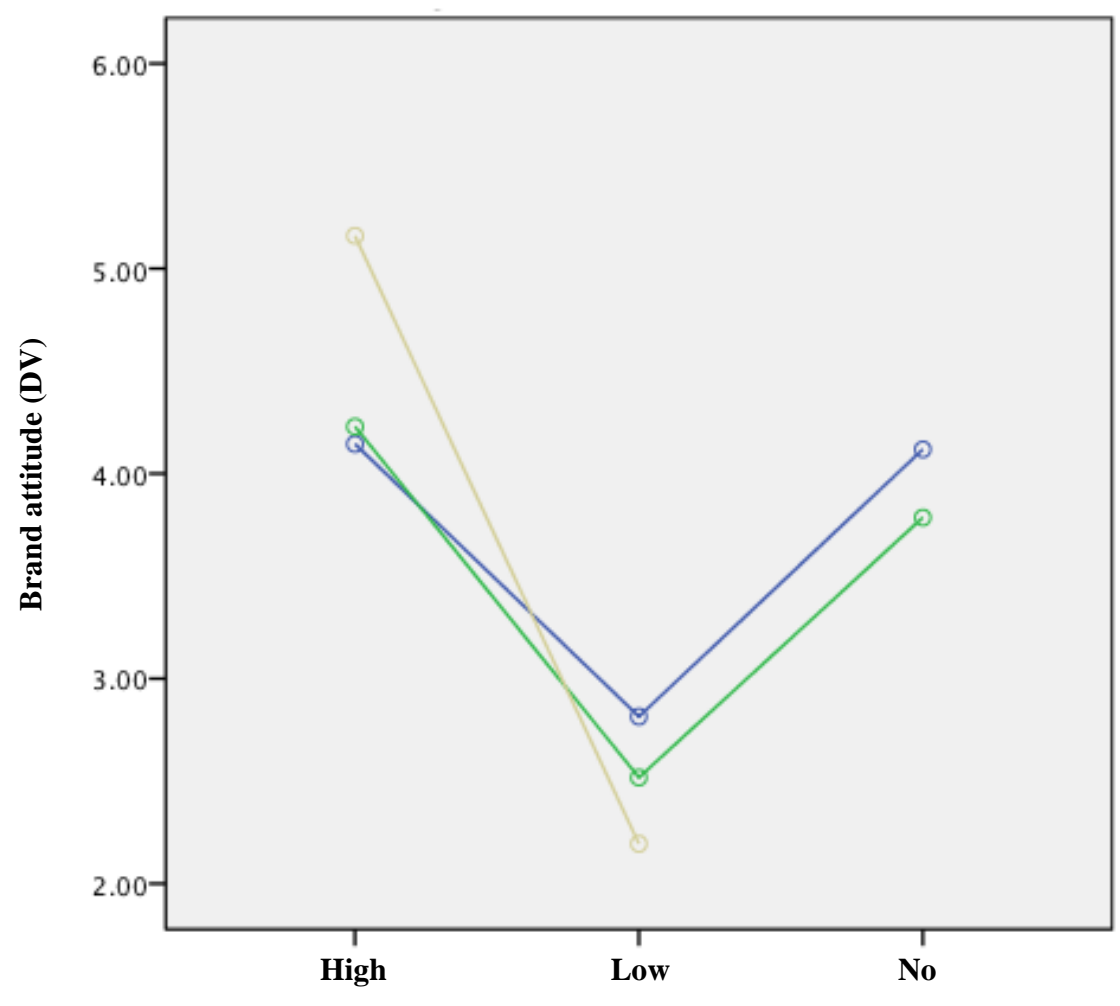

Green advertising (IV)

General corporate ad Green ad

No ad

Corporate environmental performance (IV) 
TABLE 6

Analysis of Covariance Table for Dependent Variable Brand Attitude

\begin{tabular}{lccccc}
\hline Source & \multicolumn{1}{c}{$\boldsymbol{S S}$} & $\boldsymbol{d f}$ & $\begin{array}{c}\text { Mean } \\
\text { square }\end{array}$ & $\boldsymbol{F}$ & $\boldsymbol{p}$ \\
\hline Between treatments & 353.394 & 8 & 44.174 & 31.073 & .000 \\
$\begin{array}{l}\text { Attitude toward chemical industry } \\
\text { (covariate) }\end{array}$ & 60.501 & 1 & 60.501 & 42.558 & .000 \\
Green advertising & 5.824 & 2 & 2.912 & 2.048 & .131 \\
Corporate environmental performance & 212.977 & 2 & 106.489 & 74.907 & .000 \\
$\begin{array}{l}\text { Green advertising x } \\
\text { Corporate environmental performance }\end{array}$ & 26.517 & 3 & 8.839 & 6.218 & .000 \\
Error & 402.315 & 283 & & & \\
Total & 4553.000 & 292 & & & \\
\hline
\end{tabular}

Dependent variable: Brand attitude 
TABLE 7

Analysis of Variance Table for Dependent Variable Purchase Intention

\begin{tabular}{lrrrrr}
\hline Source & \multicolumn{1}{c}{$\boldsymbol{S S}$} & $\boldsymbol{d f}$ & $\begin{array}{c}\text { Mean } \\
\text { square }\end{array}$ & $\boldsymbol{F}$ & $\boldsymbol{p}$ \\
\hline Between treatments & 302.135 & 7 & 43.162 & 23.221 & .000 \\
$\quad$ Green advertising & 6.163 & 2 & 3.081 & 1.658 & .192 \\
$\quad$ Corporate environmental performance & 246.639 & 2 & 123.320 & 66.345 & .000 \\
$\quad$ Green advertising x & 12.862 & 3 & 4.287 & 2.307 & .077 \\
$\quad$ Corporate environmental performance & & & & & \\
Within treatments & 535.325 & 288 & 1.859 & & \\
Total & 4778.000 & 296 & & & \\
\hline
\end{tabular}

Dependent variable: Purchase intention 
TABLE 8

\section{Dependent Variable Purchase Intention Means}

\begin{tabular}{llrrrr}
\hline $\begin{array}{l}\text { Green } \\
\text { advertising }\end{array}$ & $\begin{array}{l}\text { Corporate } \\
\text { environmental } \\
\text { performance }\end{array}$ & Mean & SD & & 95\% confidence interval \\
& & & & $\begin{array}{l}\text { Lower } \\
\text { bound }\end{array}$ & $\begin{array}{r}\text { Upper } \\
\text { bound }\end{array}$ \\
\hline Green ad & High & 4.406 & .241 & 3.932 & 4.881 \\
& Low & 2.447 & .221 & 2.012 & 2.883 \\
& No & 3.833 & .210 & 3.419 & 4.247 \\
\hline \multirow{2}{*}{ General corporate ad } & High & 4.433 & .249 & 3.932 & 4.881 \\
& Low & 2.704 & .261 & 2.012 & 2.883 \\
& No & 3.581 & .245 & 3.419 & 4.247 \\
\hline \multirow{2}{*}{ No } & High & 5.208 & .197 & 4.821 & 5.596 \\
& Low & 2.458 & .197 & 2.071 & 2.846 \\
& No & $-{ }^{-}$ & - & - & - \\
\hline
\end{tabular}

Dependent variable: Purchase intention

${ }^{a}$ This level combination of factors is not observed, thus the corresponding population marginal mean is not estimable. 
TABLE 9

Tukey Post Hoc Test for Dependent Variable Purchase Intention

\begin{tabular}{|c|c|c|c|c|c|c|c|}
\hline \multirow{2}{*}{$\begin{array}{l}\text { Corporate } \\
\text { environmental } \\
\text { performance }\end{array}$} & \multirow{2}{*}{$\begin{array}{l}\text { Green } \\
\text { advertising } \\
\text { (A) }\end{array}$} & \multirow{2}{*}{$\begin{array}{l}\text { Green } \\
\text { advertising } \\
\text { (B) }\end{array}$} & \multirow{2}{*}{$\begin{array}{c}\text { Mean } \\
\text { difference } \\
(A-B)\end{array}$} & \multirow{2}{*}{$S D$} & \multirow{2}{*}{$p$} & \multicolumn{2}{|c|}{$\begin{array}{l}95 \% \text { confidence } \\
\text { interval }\end{array}$} \\
\hline & & & & & & $\begin{array}{l}\text { Lower } \\
\text { bound }\end{array}$ & $\begin{array}{l}\text { Upper } \\
\text { bound }\end{array}$ \\
\hline \multirow[t]{3}{*}{ High } & Green ad & $\begin{array}{l}\text { General corporate ad } \\
\text { No ad }\end{array}$ & $\begin{array}{l}-.027 \\
-.802\end{array}$ & $\begin{array}{l}.346 \\
.311\end{array}$ & $\begin{array}{l}.938 \\
.010\end{array}$ & $\begin{array}{r}-.709 \\
-1.414\end{array}$ & $\begin{array}{r}.655 \\
-.190\end{array}$ \\
\hline & General corporate ad & $\begin{array}{l}\text { Green ad } \\
\text { No ad }\end{array}$ & $\begin{array}{r}0.27 \\
-.775\end{array}$ & $\begin{array}{l}.346 \\
.317\end{array}$ & $\begin{array}{l}.938 \\
.015\end{array}$ & $\begin{array}{r}-.655 \\
-1.400\end{array}$ & $\begin{array}{r}.709 \\
-150\end{array}$ \\
\hline & No ad & Green ad & .802 & .311 & .010 & .190 & 1.414 \\
\hline \multirow[t]{3}{*}{ Low } & Green ad & $\begin{array}{l}\text { General corporate ad } \\
\text { No ad }\end{array}$ & $\begin{array}{l}-.256 \\
-.011\end{array}$ & $\begin{array}{l}.343 \\
.296\end{array}$ & $\begin{array}{l}.456 \\
.970\end{array}$ & $\begin{array}{l}-.932 \\
-.594\end{array}$ & $\begin{array}{l}.419 \\
.572\end{array}$ \\
\hline & General corporate ad & $\begin{array}{l}\text { Green ad } \\
\text { No ad }\end{array}$ & $\begin{array}{l}.256 \\
.245\end{array}$ & $\begin{array}{l}.343 \\
.328\end{array}$ & $\begin{array}{l}.456 \\
.455\end{array}$ & $\begin{array}{l}-.419 \\
-.400\end{array}$ & $\begin{array}{l}.932 \\
.891\end{array}$ \\
\hline & No ad & $\begin{array}{l}\text { Green ad } \\
\text { General corporate ad }\end{array}$ & $\begin{array}{r}.011 \\
-.245\end{array}$ & $\begin{array}{l}.296 \\
.328\end{array}$ & $\begin{array}{l}.970 \\
.455\end{array}$ & $\begin{array}{l}-.572 \\
-.891\end{array}$ & $\begin{array}{l}.594 \\
.400\end{array}$ \\
\hline \multirow[t]{3}{*}{ No } & Green ad & $\begin{array}{l}\text { General corporate ad } \\
\text { No ad }\end{array}$ & $\begin{array}{r}.253 \\
-{ }^{a}\end{array}$ & $\begin{array}{r}.323 \\
-\end{array}$ & .434 & $\begin{array}{r}-.383 \\
-\end{array}$ & $\begin{array}{r}.888 \\
-\end{array}$ \\
\hline & General corporate ad & $\begin{array}{l}\text { Green ad } \\
\text { No ad }\end{array}$ & $\begin{array}{r}-.253 \\
-{ }_{-}^{a}\end{array}$ & $\begin{array}{r}.323 \\
-\end{array}$ & .434 & $\begin{array}{r}-.888 \\
-\end{array}$ & $\begin{array}{r}.383 \\
-\end{array}$ \\
\hline & No ad & $\begin{array}{l}\text { Green ad } \\
\text { General corporate ad }\end{array}$ & $\begin{array}{l}-^{\mathrm{a}} \\
-^{\mathrm{a}}\end{array}$ & $\begin{array}{l}- \\
-\end{array}$ & $\begin{array}{l}- \\
-\end{array}$ & $\begin{array}{l}- \\
-\end{array}$ & $\begin{array}{l}- \\
-\end{array}$ \\
\hline
\end{tabular}

Dependent variable: Purchase intention

${ }^{a}$ This level combination of factors is not observed, thus the corresponding population marginal mean is not estimable. 
FIGURE 2

Interaction Means Plot for Dependent Variable Purchase Intention

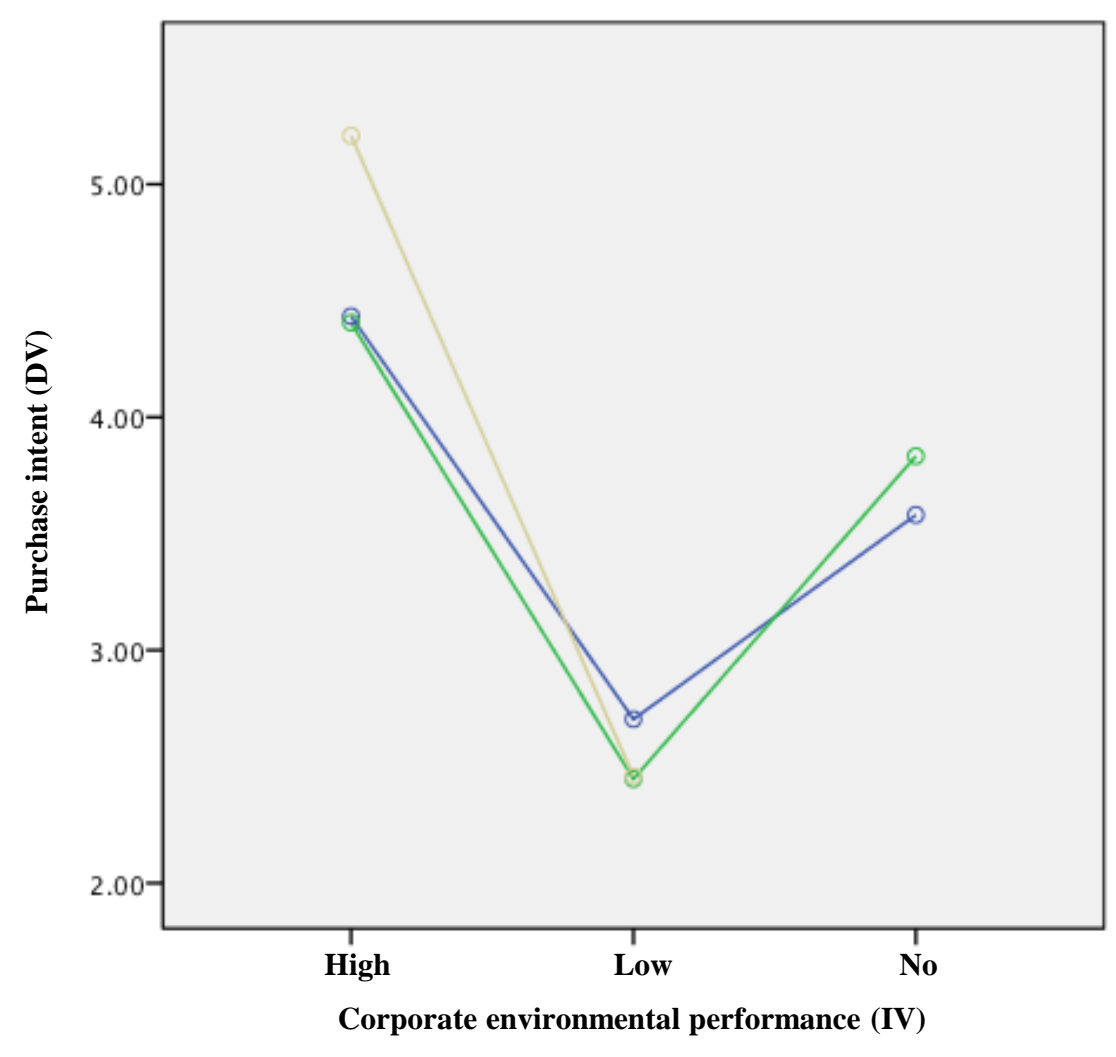

Green advertising (IV)

General corporate ad Green ad

- No ad 
TABLE 10

Analysis of Covariance Table for Dependent Variable Purchase Intention

\begin{tabular}{lccccc}
\hline Source & \multicolumn{1}{c}{$\boldsymbol{S S}$} & $\boldsymbol{d f}$ & $\begin{array}{c}\text { Mean } \\
\text { square }\end{array}$ & $\boldsymbol{F}$ & $\boldsymbol{p}$ \\
\hline Between treatments & 332.758 & 8 & 41.595 & 24.211 & .000 \\
$\begin{array}{l}\text { Attitude toward chemical industry } \\
\text { (covariate) }\end{array}$ & 35.312 & 1 & 35.312 & 20.554 & .000 \\
Green advertising & 7.927 & 2 & 3.964 & 2.307 & .101 \\
Corporate environmental performance & 241.054 & 2 & 120.527 & 70.154 & .000 \\
$\begin{array}{l}\text { Green advertising x } \\
\text { Corporate environmental performance }\end{array}$ & 13.734 & 3 & 4.578 & 2.665 & .048 \\
Error & 486.201 & 283 & 1.718 & & \\
Total & 4696.000 & 292 & & & \\
\hline
\end{tabular}

Dependent variable: Purchase intention 


\section{Appendix 1}

\section{Advertising and Corporate Environmental Performance Scenario Stimuli}

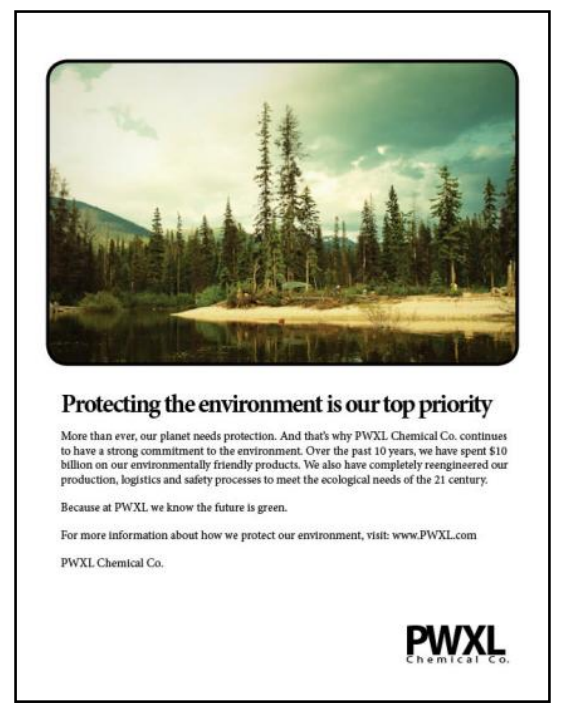

Green Advertisement

(Test)

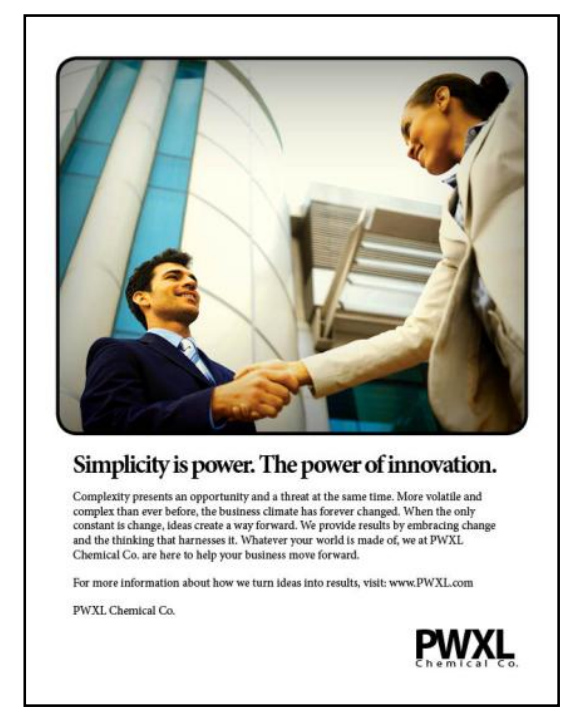

General Corporate Advertisement (Control)
"Now imagine that you learned just recently that PWXL Chemicals has just won an award for the "best environmentally friendly company" in the chemical category from the United States Environmental Protection Agency.

The award is the highest form of acclaim for corporate environmental protection efforts. It is a proof that PWXL Chemicals has extremely high standards in environmental practices and overall positive impact on the environment."

\section{High Environmental Performance} (Test)
"Now imagine that you learned that PWXL Chemicals was responsible for a major environmental catastrophe recently - a large scale chemical leak in one of their US-based plants.

The chemical spill did not only cause severe ecological damage but was responsible for the death of several workers at the plant. Federal investigation showed that without question it was the firm's subpar environmental standards and managerial negligence that caused the environmental catastrophe."

\section{Low Environmental Performance} (Control) 


\section{References}

Alves, I. M. (2009). Green spin everywhere: How greenwashing reveals the limits of the CSR paradigm. Journal of Global Change \& Governance, 2(1), 1-26.

Banerjee, S., Gulas, C. S., \& Iyer, E. (1995). Shades of green: A multidimensional analysis of environmental advertising. Journal of Advertising, 24(2), 21-31.

Brammer, S. J. \& Pavelin, S. (2006). Corporate reputation and social performance: The importance of fit. Journal of Management Studies, 43(3), 435-455.

Cho, C. H., Guidry, R. P., Hageman, A. M., \& Patten, D. M. (2012). Do actions speak louder than words? An empirical investigation of corporate environmental reputation. Accounting, Organizations \& Society, 37(1), 14-25.

Colley, R. H. (1961). Defining advertising goals for measured advertising results. New York: Association of National Advertisers.

Cronin Jr., J. J., Smith, J., Gleim, M., Ramirez, E., \& Martinez, J. (2011). Green marketing strategies: An examination of stakeholders and the opportunities they present. Journal of the Academy of Marketing Science, 39(1), 158-174.

Dahlstrom, R. (2010). Green marketing management. Mason, OH: South-Western.

Davis, J. J. (1992). Ethics and environmental marketing. Journal of Business Ethics, 11(2), 8187.

Davis, J. J. (1993). Strategies for environmental advertising. Journal of Consumer Marketing, 10(2), 19-36.

Davis, J. J. (1994). Good ethics is good for business: Ethical attributions and response to environmental advertising. Journal of Business Ethics, 13(11), 873-885.

Delmas, M., \& Blass, V. D. (2010). Measuring corporate environmental performance: The trade- 
offs of sustainability ratings. Business Strategy \& the Environment, 19(4), 245-260.

Delmas, M. A., \& Burbano, V. C. (2011). The drivers of greenwashing. California Management Review, 54(1), 64-87.

Easterling, D., Kenworthy, A., \& Nemzoff, R. (1996). The greening of advertising: A twentyfive year look at environmental advertising. Journal of Marketing Theory \& Practice, 4(1), 20-33.

Ellen, P. S., Webb, D. J., \& Mohr, L. A. (2006). Building corporate associations: Consumer attributions for corporate socially responsible programs. Journal of the Academy of Marketing Science, 34(2), 147-157.

Folkes, V. S. (1988). Recent attribution research in consumer behavior: A review and new directions. Journal of Consumer Research, 14(4), 548-565.

Folkes, V. S., \& Kamins, M. A. (1999). Effects of information about firms' ethical and unethical actions on consumers' attitudes. Journal of Consumer Psychology, 8(3), 243-259.

Forbes (2012, February). BP goes for public relations makeover to get beyond Gulf spill. Forbes. Retrieved March 29, 2012 from http://www.forbes.com/sites/greatspeculations/2012/02/07/bp-goes-for-public-relations$\underline{\text { makeover-to-get-beyond-gulf- spill/?utm_source=dlvr.it\&utm_medium=twitter. }}$

Forehand, M. R., \& Grier, S. (2003). When is honesty the best policy? The effect of stated company intent on consumer skepticism. Journal of Consumer Psychology, 13(3), 349356.

Friestad, M., \& Wright, P. (1994). The persuasion knowledge model: How people cope with persuasion attempts. Journal of Consumer Research, 21(1), 1-31.

Furlow, N. E. (2010). Greenwashing in the new millennium. Journal of Applied Business and 
Economics, 10(6), 22-25.

Geue, M., \& Plewa, C. (2010). Cause sponsorship: A study on congruence, attribution and corporate social responsibility. Journal of Sponsorship, 3(3), 228-241.

GfK. (2010). American consumers lead the world in environmental skepticism. Retrieved May 1, 2013 from http://www.gfkamerica.com/newsroom/press_releases/single_sites/006588/index.en.html.

Gillespie, E. (2008). Stemming the tide of 'greenwash'. Consumer Policy Review, 18(3), 79-83.

Greer, J., \& Bruno, K. (1996). Greenwash: The reality behind corporate environmentalism. New York: Apex Press.

Groza, M., Pronschinske, M., \& Walker, M. (2011). Perceived organizational motives and consumer responses to proactive and reactive CSR. Journal of Business Ethics, 102(4), 639-652.

Gunningham, N. (2009). Shaping corporate environmental performance: A review. Environmental Policy \& Governance, 19(4), 215-231.

Hair, J. F., Black, W. C., Babin, B. J., \& Anderson, R. E. (2010). Multivariate data analysis. Upper Saddle River, NJ: Prentice Hall.

Harvey, J. H., \& Weary, G. (1984). Current issues in attribution theory and research. Annual Review of Psychology, 35(1), 427-459.

Heider, F. (1944). Social perception and phenomenal causality. Psychological Review, 51(6), 358-374.

Henion, K. E. (1972). The effect of ecologically relevant information on detergent sales. Journal of Marketing Research, 9(1), 10-14.

Kelley, H. H. (1971). Attribution in social interaction. New York: General Learning Press. 
Kelley, H. H., \& Michela, J. L. (1980). Attribution theory and research. Annual Review of Psychology, 31(1), 457-501.

Kerton, R. R., \& Bodell, R. W. (1995). Quality, choice, and the economics of concealment: The marketing of lemons. Journal of Consumer Affairs, 29(1), 1-28.

Klein, J., \& Dawar, N. (2004). Corporate social responsibility and consumers' attributions and brand evaluations in a product-harm crisis. International Journal of Research in Marketing, 21(3), 203-217.

Klein, B., \& Leffler, K. B. (1981). The role of market forces in assuring contractual performance. Journal of Political Economy, 89(4), 615-641.

Kotler, P. (2011). Reinventing marketing to manage the environmental imperative. Journal of Marketing, 75(4), 132-135.

Lee, M. P., \& Lounsbury, M. (2011). Domesticating radical rant and rage: An exploration of the consequences of environmental shareholder resolutions on corporate environmental performance. Business \& Society, 50(1), 155-188.

Leonidou, C. N., \& Leonidou, L. C. (2011). Research into environmental marketing/management: A bibliographic analysis. European Journal of Marketing, 45(1/2), 68-103.

Martin, D., \& Schouten, J. (2012). Sustainable marketing. Boston, MA: Prentice Hall.

Mitchell, A. A., \& Olson, J. C. (1981). Are product attribute beliefs the only mediator of advertising effects on brand attitude? Journal of Marketing Research, 18(3), 318-332.

Mizerski, R. W., Golden, L. L., \& Kernan, J. B. (1979). The attribution process in consumer decision making. Journal of Consumer Research, 6(2), 123-140.

Mobley, A. S., Painter, T. S., Untch, E. M., \& Unnava, H. R. (1995). Consumer evaluation of 
recycled products. Psychology \& Marketing, 12(3), 165-176.

Montoro-Rios, F. J., Luque-Martinez, T., \& Rodriguez-Molina, M.-A. (2008). How green should you be: Can environmental associations enhance brand performance? Journal of Advertising Research, 48(4), 547-563.

Muehling, D. D., \& Laczniak, R. N. (1988). Advertising's immediate and delayed influence on brand attitudes: Considerations across message-involvement levels. Journal of Advertising, 17(4), 23-34.

Newell, S. J., Goldsmith, R. E., \& Banzhaf, E. J. (1998). The effect of misleading environmental claims on consumer perceptions of advertisements. Journal of Marketing Theory \& Practice, 6(2), 48-60.

Öberseder, M., Schlegelmilch, B., \& Gruber, V. (2011). 'Why don't consumers care about CSR?': A qualitative study exploring the role of CSR in consumption decisions. Journal of Business Ethics, 104(4), 449-460.

Oliver, R. L. (1993). Cognitive, affective, and attribute bases of the satisfaction response. Journal of Consumer Research, 20(3), 418-430.

Paladino, A., \& Pandit, A. P. (2012). Competing on service and branding in the renewable electricity sector. Energy Policy, 45, 378-388.

Parguel, B., Benoît-Moreau, F., \& Larceneux, F. (2011). How sustainability ratings might deter 'greenwashing': A closer look at ethical corporate communication. Journal of Business Ethics, 102(1), 15-28.

Petty, R. E., \& Cacioppo, J. T. (1986). Communication and persuasion: Central and peripheral routes to attitude change. New York: Springer-Verlag.

Polonsky, M. J. (1995). A stakeholder theory approach to designing environmental marketing 
strategy. Journal of Business \& Industrial Marketing, 10(3), 29-46.

Polonsky, M. J. (2011). Transformative green marketing: Impediments and opportunities. Journal of Business Research, 64(12), 1311-1319.

Porter, M. E., \& Kramer, M. R. (2006). Strategy \& society: The link between competitive advantage and corporate social responsibility. Harvard Business Review, 84(12), 78-92.

Raju, S. and Rajagopal, P. (2008). Responding to ethical and competence failures. Advances in Consumer Research, 35, 855-856.

Ramus, C. A., \& Montiel, I. (2005). When are corporate environmental policies a form of greenwashing? Business \& Society, 44(4), 377-414.

Salo, J. (2008). Corporate governance and environmental performance: Industry and country effects. Competition and Change, 12(4), 328-354.

Schuhwerk, M. E., \& Lefkoff-Hagius, R. (1995). Green or non-green? Does type of appeal matter when advertising a green product? Journal of Advertising, 24(2), 45-54.

Singh, J., Salmones Sanchez, M. d. M. G., \& Bosque, I. R. (2008). Understanding corporate social responsibility and product perceptions in consumer markets: A cross-cultural evaluation. Journal of Business Ethics, 80(3), 597-611.

Swaen, V., \& Vanhamme, J. (2004). See how 'good' we are: The dangers of using corporate social activities in communication campaigns. Advances in Consumer Research, 31, 302303.

TerraChoice. (2010). The sins of greenwashing: Home and family edition 2010: A report on environmental claims made in the North American consumer market. Retrieved December 18, 2011 from http://sinsofgreenwashing.org/?dl_id=102.

Vanhamme, J., \& Grobben, B. (2009). “Too good to be true!”. The effectiveness of CSR history 
in countering negative publicity. Journal of Business Ethics, 85(Supplement 2), 273-283.

Vlachos, P. A., Tsamakos, A., Vrechopoulos, A. P., \& Avramidis, P. K. (2009). Corporate social responsibility: Attributions, loyalty, and the mediating role of trust. Journal of the Academy of Marketing Science, 37(2), 170-180.

Walker, M., Heere, B., Parent, M., \& Drane, D. (2010). Social responsibility and the Olympic games: The mediating role of consumer attributions. Journal of Business Ethics, 95(4), 659-680.

Webb, D. J., \& Mohr, L. A. (1998). A typology of consumer responses to cause-related marketing: From skeptics to socially concerned. Journal of Public Policy \& Marketing, 17(2), 226-238.

Weiner, B. (1986). An attributional theory of motivation and emotion. New York: SpringerVerlag.

Weiner, B. (2000). Attributional thoughts about consumer behavior. Journal of Consumer Research, 27(3), 382-387.

Xie, S., \& Hayase, K. (2007). Corporate environmental performance evaluation: A measurement model and a new concept. Business Strategy \& the Environment, 16(2), 148-168.

Yoon, Y., Gürhan-Canli, Z., \& Schwarz, N. (2006). The effect of corporate social responsibility (CSR) activities on companies with bad reputations. Journal of Consumer Psychology, 16(4), 377-390.

Zinkhan, G. M., \& Carlson, L. (1995). Green advertising and the reluctant consumer. Journal of Advertising, 24(2), 1-6. 


\section{Ethical Statement}

This study has been approved by the University of Oregon's Institutional Review Board for Human Subjects Research and has been performed in accordance with the ethical standards laid down in the 1964 Declaration of Helsinki. All persons gave their informed consent prior to their inclusion in the study.

\section{Conflict of Interest Statement}

No external organization sponsored this study. Accordingly, there are no potential conflicts of interest to report. 


\section{University Library}

\section{- M M I N E R VA \\ A gateway to Melbourne's research publications}

Minerva Access is the Institutional Repository of The University of Melbourne

Author/s:

Nyilasy, G;Gangadharbatla, H;Paladino, A

Title:

Perceived Greenwashing: The Interactive Effects of Green Advertising and Corporate Environmental Performance on Consumer Reactions

Date:

2014-12-01

\section{Citation:}

Nyilasy, G., Gangadharbatla, H. \& Paladino, A. (2014). Perceived Greenwashing: The Interactive Effects of Green Advertising and Corporate Environmental Performance on Consumer Reactions. JOURNAL OF BUSINESS ETHICS, 125 (4), pp.693-707. https:// doi.org/10.1007/s10551-013-1944-3.

Persistent Link:

http://hdl.handle.net/11343/282809 